Teknomekanik

Vol.3, No.1, May 2020, pp. $22 \sim 27$

\title{
Hardness Analysis of Stone Breaker Chisel Made of Medium Carbon Steel as a Result of Hardening Using Water Cooling Media
}

\author{
Alan Novendra ${ }^{1}$, Refdinal ${ }^{2}$ and Sai Kham Le $^{3}$ \\ ${ }^{1-2}$ Jurusan Teknik Mesin, Fakultas Teknik, Universitas Negeri Padang, Indonesia \\ ${ }^{3}$ Mechanical Department, Faculty of Engineering, King Mongkut's Institute of Technology Ladkrabang, Thailand
}

\begin{tabular}{l}
\hline Article Info \\
\hline Article history: \\
Received January $09^{\text {th }}, 2020$ \\
Revised March $10^{\text {th }}, 2020$ \\
Accepted April $25^{\text {th }}, 2020$ \\
\hline
\end{tabular}

Keywords:

Stone chisels

Hardening

Leaf spring

Brinell

\begin{abstract}
Stone chisels produced by blacksmiths which are made using leaf spring steel are often too brittle or fragile so that when they are used, they often occur in the form of cracks and breaks. This study aims to determine the appropriate hardness level for stone chisels. The process is carried out by comparing the hardness level of stone chisels that have been used but still in good condition and those that have been damaged. Broken stone chisels have a high adequate hardness compared to good stone chisels so that damaged stone chisels can be reconditioned to get the right rock chisel hardness. Heat treatment is given to damaged stone chisels to improve the hardness level by normalizing the process to restore the initial mechanical properties of the steel and increasing the hardness of the chisel by heating the steel and then quenching it using water cooling media. Based on the experimental process carried out that the hardness level of a good stone chisel is between $228 \mathrm{HB}$ to $320 \mathrm{HB}$ by heating the duan spring steel to a temperature of $780^{\circ} \mathrm{C}$ with a hold time of 10 minutes then cooling it quickly using water and stone chisels can break when it is used because it has a very high hardness.
\end{abstract}

Copyright $(0) 2020$ Universitas Negeri Padang. All rights reserved.

\section{Corresponding Author:}

Alan Novendra,

Mechanical Engineering, Engineering Faculty,

Universitas Negeri Padang,

Jln. Prof. Dr. Hamka Air Tawar, Padang (25131)

Sumatera Barat, Indonesia

Email: alansingkuang@gmail.com

\section{INTRODUCTION}

Andesite or lavastone is a rock composed of fine-grained minerals dominated by gray or red [1]. One of the andesite stone quarries is in Nagari Pandam Gadang, Gunuang Omeh District, Lima Puluh Kota Regency, West Sumatera. In addition, andesite is produced into sharpening stones and marketed to Sumatra, Java, and Kalimantan. Tools being used to mine the rock are chisels, crowbar, and hammers. The stone chisels used were produced by blacksmiths by using Duan spring steel. Unfortunately, the stone chisels being produced do not have a good quality. Stone chisels break easily when they are used because they are too brittle. The stone chisel is made of car leaf spring steel that consists of several thin, curved plates [2]. Leaf springs are a component that absorbs shocks on vehicles caused by uneven road surfaces [3]. Leaf springs are a type of spring that can accept heavy loads compared to other types of springs and are often used in car rear suspension [4]. Leaf spring steel consists of the elements iron (Fe), carbon (C), manganese ( $\mathrm{Mn})$ [5]. The carbon content of car leaf springs is $0.4 \% \mathrm{C}$ [6]. The carbon content determines the hardness level [7]. Steel is divided into three types based on its carbon content, namely low, medium carbon steel and high carbon steel [8]. Based on the carbon content, leaf spring steel is classified as medium carbon steel and can be heat treated [9].

As a matter of fact, heat treatment is an essential process in the manufacturing process because it has a 
direct effect on the product quality [10]. Heat treatment is a process carried out on steel to improve mechanical properties [11]. Heat treatment can also occur accidentally as a result of the process being carried out on steel. The heat treatment process is to heat the metal to a certain temperature with a certain holding time and then cool it to various levels [12]. One of the mechanical properties that can be changed by heat treatment is the hardness [13].

Furthermore, the good qtuality stone chisels are hard and ductile. So the stone chisels used will be more resistant to wear and not easily cracked or broken. The right hardening process will produce good quality stone chisels. Hardening process is heating the steel to austenite temperature with a holding time [14]. Holding Time aims to get homogeneous heating so that the austenite is also homogeneous [15]. Then, it is followed by rapid cooling to produce a microstructure that increases the hardness of the steel [16]. The microstructure formation process can be affected by the cooling rate [17]. The microstructure formed due to the cooling rate will affect the hardness and toughness of the steel [18]. With the right rock chisel hardness, the stone cutting process is not hampered by lack of chisels due to fractures.

To increase the hardness value, the specimens are heated and followed by a quenching process [19]. This process is widely used because its cost is inexpensive[20]. To determine the quenching temperature, it can be seen in the Continuous Cooling Transformation (CCT) diagram. The CCT diagram is a depiction of the relationship between the continuous cooling rate and the phase or structure formed by phase transformation [21]. The structure formed during the cooling process will affect the resulting hardness [22]. Because each structure has a different hardness [23]. The cooling medium used in the quinching process is water.

\section{METHOD}

This research method is carried out by the experimental research method, the specimen that will be the object of research is the traditional blacksmith-made stone chisel. Stone chisels being used as research specimens are stone chisels that have been used or used by stone miners. The experimental process performs reconditioning of damaged or broken chisels so that they have the same hardness level as good condition tools. Chisels that have been used and still in good condition have hardness at the base of the tool $228 \mathrm{HB}$ and at the point of the tool has hardness of $320 \mathrm{HB}$. The process of reconditioning damaged chisels can be seen in Figure 1.

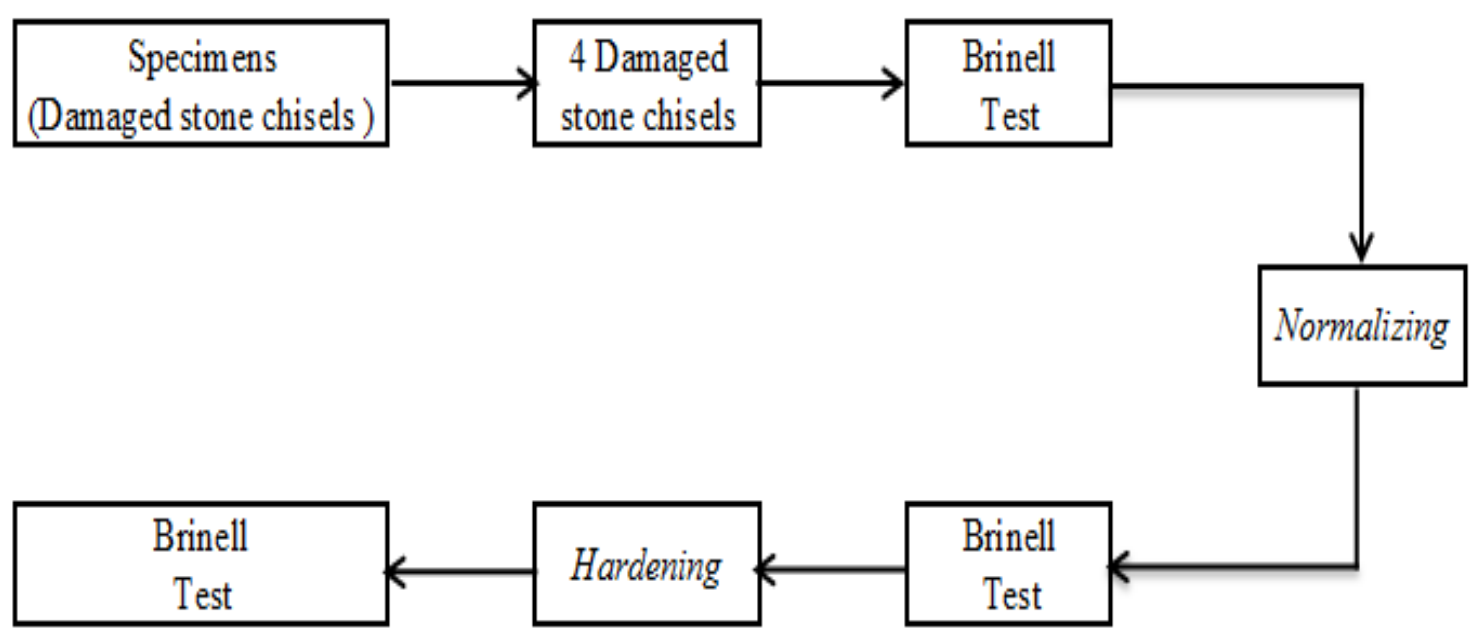

Figure 1. the processes 


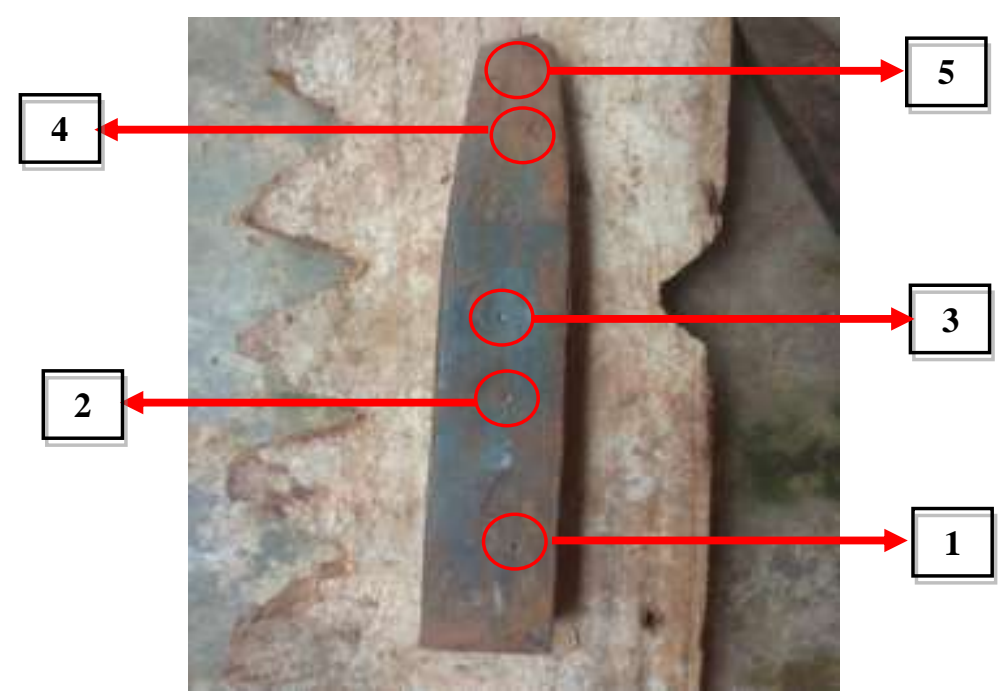

Figure 2. Specimen Measurement Points

Damaged stone chisels will be undertaken to a shape reconditioning process. After that, a heat treatment process is carried out to obtain the same hardness value with a good quality chisel. Heat treatment is given by normalizing process and quenching process. In fact, the normalizing process aims to restore the original properties of the steel. This process is carried out using a temperature of $720^{\circ} \mathrm{C}$ and a holding time of 20 minutes and then being cooled using the room temperature. The results of the normalizing process will be tested again with the same technique with 3 measurement points for each specimen. To increase the hardness value of the tool, it needs a hardening process using a temperature of $780^{\circ} \mathrm{C}$ and a holding time of 10 minutes and being cooled quickly using water cooling media. The results of the hardening process were performed using brineel test for 5 measurement points.

In the hardness test using the brinell method, the loading is given through an indenter (steel ball) which is touched to the surface of the object so that it causes indentation [24]. The amount of loading (P) can be determined by the constant of the material to be tested (C) multiplied by the diameter of the indenter used(D) (Equation 1). To determine the brinell hardness value (HBN), the load size $(\mathrm{P})$ is divided by the indenter diameter (D) minus the trace diameter on the surface of the specimen (d) (Equation 2). The brinell test uses a load of $750 \mathrm{~kg}$ with an indenter of $5 \mathrm{~mm}$ in diameter and a press holding time of 10 seconds.

$$
\begin{aligned}
P & =C x \mathrm{D} \ldots \ldots \ldots \\
H B & =\frac{2 P}{\pi D\left(D-\sqrt{D^{2}-d^{2}}\right)} .
\end{aligned}
$$

\section{RESULTS AND DISCUSSION}

The results of initial specimen testing can be seen in Table 1. The high level of hardness value of the rock chisel specimen is compared to a good rock chisel which has a hardening value of 320 HB. Broken stone chisel specimens have high level of hardness in the damaged chisel part. The average hardness value of damaged stone chisels is above $550 \mathrm{HB}$. The higher the hardness of steel, the more brittle the steel will be [25]

Table 1. Initial Hardness Testing

\begin{tabular}{lccccccc}
\hline & \multirow{2}{*}{ No } & \multirow{2}{*}{ Condition } & Specimens & \multicolumn{5}{c}{ Hardness Brinell } \\
\cline { 4 - 7 } & & & 1 & 2 & 3 & 4 & 5 \\
\hline 1 & Damagaed & 1 & 363.39 & 477.7 & 414.84 & 477.70 & 555.61 \\
& 2 & 206.62 & 206.62 & 254.73 & 477.7 & 653.78 \\
& 3 & 284.99 & 254.73 & 320.74 & 254.73 & 555.61 \\
& & & 254.73 & 254.73 & 284.99 & 320.74 & 653.78 \\
\hline
\end{tabular}

\footnotetext{
Journal homepage: http:// http://teknomekanik.ppj.unp.ac.id
}

DOI: $\underline{\text { https://doi.org/10.24036/tm.v3i1.5172 }}$ 
Based on the initial test data, it can be seen that the stone chisels do not have an even level of hardness. Stone chisels have a higher level of hardness at the cutting edge of the chisel. To carry out the reconditioning process of damaged chisels, a normalizing process is needed. The normalizing process aims to restore the initial mechanical properties of the steel so that the hardness of the tool becomes even. [26]. The brinell test results of damaged stone chisel specimens after being reconditioned and given normalizing heat treatment can be seen in table 2 .

Table 2. Normalizing Result Hardness Testing

\begin{tabular}{ccccccc}
\hline \multirow{2}{*}{ No } & \multirow{2}{*}{ Condition } & \multirow{2}{*}{ Specimens } & \multicolumn{4}{c}{ Hardness Brinell } \\
\cline { 4 - 6 } & & & 1 & 2 & 3 \\
\hline 1 & Recondition & 1 & 228.88 & 228.88 & 228.88 \\
& & 2 & 228.88 & 206.62 & 228.88 \\
& 3 & 228.88 & 228.88 & 228.88 \\
& 4 & 228.88 & 228.88 & 228.88 \\
\hline
\end{tabular}

The hardness of specimens that have finished the normalizing process is increased by being treated with the hardening process with water cooling media. The results of the brinell specimen test can be seen in table 3.

Table 3. Quenching Hardness Testing Results

\begin{tabular}{rrrrrrrr}
\hline \multirow{2}{*}{ No } & \multirow{2}{*}{ Condition } & \multirow{2}{*}{ Specimens } & \multicolumn{5}{c}{ Hardness Brinell } \\
\cline { 3 - 7 } & & & 1 & 2 & 3 & 4 & 5 \\
\hline 1 & Recondition & 3 & 228.88 & 228.88 & 254.73 & 254.73 & 320.74 \\
\hline
\end{tabular}

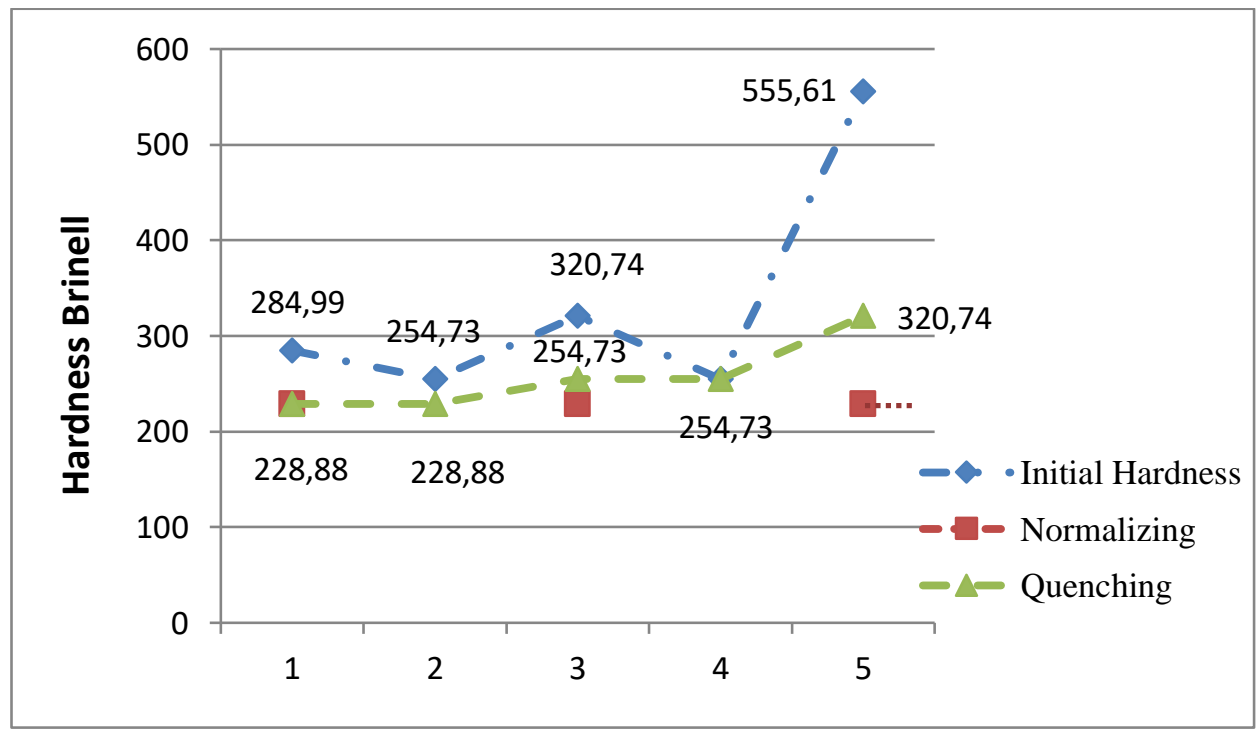

Figure 3. Violence Change Diagram

From the graph above, the comparison of the hardness of the stone chiselscan be seen. Stone chisels break easily when it is used because the hardness is too high. In fact, tt can be seen from Figure 3 that the broken part of the chisel has a hardness level above $500 \mathrm{HB}$. The brittleness of steel is directly proportional to the hardness of the steel. The normalization process of steel serves to restore the initial mechanical properties of the steel. In addition, the chisel hardness value after normalizing process is $228 \mathrm{HB}$. So that the process of increasing the hardness of steel is easierbecause the steel returns to its initial properties with the 
even hardness. By possessing the same hardness level, it becomes more effortless to get the desired hardness. To increase the hardness level of the tool aims to make the tools become more wear-resistant and ductile [27]. From the graph, it can be seen that a good stone chisel has a hardness between $228 \mathrm{HB}$ and $320 \mathrm{HB}$.

\section{CONCLUSION}

Based on the results of the study, it can be concluded that the damaged stone chisels occurred because the hardness level was excessive. As a result, the stone chisel becomes brittle so that it is easy to break or crack when it is used. From the test results, it is obtained the correct hardness value for a stone chisel is between $228 \mathrm{HB}$ to $320 \mathrm{HB}$. The hardness value is obtained by increasing the hardness of the stone chisel by heating the chisel to $780^{\circ} \mathrm{C}$ with a holding time of 10 minutes and then cooling it quickly using water cooling media. Stone chisels also bend easily if they have a hardness value below $228 \mathrm{HB}$. The process of reconditioning stone chisels is by normalizing heat treatment to restore the initial mechanical properties and hardening to increase the hardness of the stone chisel. Increasing the hardness of stone chisels can only be done on the cutting edge of the chisel or only partially hardening. In short, stone chisels which have the right hardness value will withstand the timeworn, thus the usage duration of the chisels will be in a longer period.

\section{REFERENCES}

[1] T. Imron, R. S. S. Nazli dan S. Raharja, "Strategi Pengembangan Pemasaran Batu Andesit (Studi Kasus pada PT Duta Keluarga Imfaco, Bogor Jawa Barat)", Jurnal Manajemen IKM, vol.13, (2), pp. 127-136, September 2018.

[2] O. R. Adetunji, P. O. Aiyedun, S. O. Ismaila, and M. J. Alao, "Effect of Normalizing and Hardening on Mechanical Properties of Spring," J. Miner. Mater. Charact. Eng., vol. 11, no. 08, pp. 832-835, 2012, doi: 10.4236/jmmce.2012.118074.

[3] A. D. Halimi dan M. A. Irfa'i, "Uji Eksperimen tingkat Kekerasan Dan Ketangguhan Baja Pegas Jis Sup 9 Dengan Metode Laku Panas Hardening Dan Tempering ", Jurnal Teknik Mesin, vol. 5, (3), pp. 45-52, 2017.

[4] D. Ristyadi, " Analia Kekeraan Dan Struktur Mikro Hail Perlakuan Panas (Hardening) Baja Pegas Daun Dengan Pendinginan Sistem Pancaran Pada Tekanan Berbeda", Jurnal Pendidikan Teknik Mesin, vol. 1, (3), 2015.

[5] Jasman, Hotmartua dan Syahrul, "Effect Tampering and Normalizing On Steel Spring Leaf", Jurnal Mekanik, vol.12, pp. 108-116 2018.

[6] R. J. Dimu., D. Widhiyanuriyawan dan Sugiono, "Optimasi Hardening Baja Karbon Sedang dengan Fluida Getah Pohon Pisang Menggunakan Metode Taguchi", Jurnal Rekayasa Mesin, vol. 5, (2), pp. 135-140, 2014.

[7] M. Tolouei-Rad and E. Lichter, "The heat treatment analysis of E110 case hardening steel," J. Eng. Sci. Technol., vol. 11, no. 3, pp. 407-415, 2016.

[8] T. Fazli, N. Erizon, and J. Adri, "Experimental Test of Annealing Process on SMAW at Low Carbon Steel Toughness," vol. 1, no. 1, pp. 32-35, 2018.

[9] Z. A. Putra, Pengetahuan Bahan Teknik, Padang: Teknik Mesin Universitas Negeri Padang, 2013.

[10] R. Fragoudakis, S. Karditsas, G. Savaidis, and N. Michailidis, "The Effect of Heat and Surface Treatment on the Fatigue Behaviour of 56SiCr7 Spring Steel," in Procedia Engineering, 2014, pp. 309 $-312$.

[11] Am. Mufarrih ., Mohammad, M. I., Agus, S. N. Analisa Kekerasan Pisau Hasil Ukm Pandai Besi Pada Proses Perlakuan Panas. Seminar Nasional Multidisiplin. Jombang. 2018: 147- 151.

[12] J. B. Wiskel et al., “ $\square$ Study the Effect on the Hardness of three Sample Grades of Tool Steel i . e . EN31 , EN-8, and D3 after Heat Treatment Processes Such As Annealing, Normalizing, and Hardening \& Tempering Ashish Bhateja," Int. J. Eng. Sci., vol. 1, no. 1, pp. 1-10, 2012, doi: 10.1016/00255416(85)90104-1.

[13] G. Li, S. Tian, and Y. Wang, "Effect of heat treatment on microstructure and mechanical properties of low carbon chromium steel," Jinshu Rechuli/Heat Treat. Met., vol. 37, no. 5, pp. 46-49, 2012.

Journal homepage: http:// http://teknomekanik.ppj.unp.ac.id

DOI: https://doi.org/10.24036/tm.v3i1.5172 
[14] H. Nurdin and M. Mulianti, "Pengaruh Bentuk Takikan (Notched) pada Poros Baja Karbon ST. 60 Akibat Beban Tarik," J. Tek. Mesin, vol. 8, no. 1, pp. 50-54, 2011.

[15] Peryanto, "Analisa Pengaruh Media Perlakuan Panas Quenching terhadap Kekerasan dan Struktur Mikro Baja Karbon Sedan",. JURNAL TEKNIK MESIN UBL, vol. 4, (1), pp. 21-26, 2016.

[16] Z. Fatoni, "Pengaruh Perlakuan Panas terhadap Baja Paduan Rendah untuk Bahan Pisau Penyayat Karet", Jurnal Desiminasi Teknologi vol. 4, (1), pp. 56-63, Januari 2016.

[17] Basori, "Pengaruh Media Quenching Terhadap Kekerasan Dan Struktur Mikro Paska Hardfacing", Jurnal Kajian Teknik Mesin, vol. 3, (2) pp. 66-72, 2018.

[18] M. C. Zhao, K. Yang, F. R. Xiao, and Y. Y. Shan, "Continuous cooling transformation of undeformed and deformed low carbon pipeline steels," Mater. Sci. Eng. A, vol. 355, no. 1-2, pp. 126-136, 2003, doi: 10.1016/S0921-5093(03)00074-1.

[19] H. J. Jun, J. S. Kang, D. H. Seo, K. B. Kang, and C. G. Park, "Effects of deformation and boron on microstructure and continuous cooling transformation in low carbon HSLA steels," Mater. Sci. Eng. A, vol. 422, no. 1-2, pp. 157-162, 2006, doi: 10.1016/j.msea.2005.05.008.

[20] C. Şimşir and C. H. Gür, "3D FEM simulation of steel quenching and investigation of the effect of asymmetric geometry on residual stress distribution," J. Mater. Process. Technol., vol. 207, no. 1-3, pp. 211-221, 2008, doi: 10.1016/j.jmatprotec.2007.12.074.

[21] T. L. Steel, "Nanoindentation-Based Micro-Mechanical and Electrochemical Properties of QuenchHardened, Tempered Low-Carbon Steel," Crystals, vol. 10, no. 508, pp. 1-11, 2020.

[22] B. Lisci'c, H. M. Tensi, L. C. F. Canale, and G. E. Totten, Eds., Quenching Theory And Technology, Second. Boca Raton London New York: Taylor \& Francis Group, 2010.

[23] S. M. M. Rahman, K. E. Karim, and M. H. S. Simanto, "Effect of Heat Treatment on Low Carbon Steel: An Experimental Investigation," Appl. Mech. Mater., vol. 860, pp. 7-12, 2016, doi: 10.4028/www.scientific.net/amm.860.7.

[24] B. Sayed Shafayat Hossain, M. Maksudul Islam, M. Sajibul Alam Bhuyan, S. Shafayat Hossain $\alpha$, M. Maksudul Islam $\sigma$, and M. Sajibul Alam Bhuyan $\rho$, "A Case Study of Heat Treatment on AISI 1020 Steel," Glob. J. Res. Eng., vol. 14, no. 5, pp. 0-5, 2014.

[25] G. Leyi, Z. Wei, Z. Jing, and H. Songling, "Mechanics analysis and simulation of material Brinell hardness measurement," Meas. J. Int. Meas. Confed., vol. 44, no. 10, pp. 2129-2137, 2011, doi: 10.1016/j.measurement.2011.07.024.

[26] O. R. Adetunji, D. Ph, S. I. Kuye, D. Ph, M. J. Alao, and B. Eng, "Microstructures of Mild Steel Spring after Heat Treatment. Microstructures of Mild Steel Spring after Heat Treatment .," vol. 14, no. February, pp. 11-15, 2015.

[27] V. B. Da et al., "Normalizing Heat Treatment Effect on Low Alloy Steel Weld Metals," 2004.

[28] E. Abbasi, Q. Luo, and D. Owens, "A comparison of microstructure and mechanical properties of lowalloy-medium-carbon steels after quench-hardening," Mater. Sci. Eng. A, vol. 725, pp. 65-75, 2018, doi: 10.1016/j.msea.2018.04.01

Journal homepage: http:// http://teknomekanik.ppj.unp.ac.id

DOI: https://doi.org/10.24036/tm.v3i1.5172 